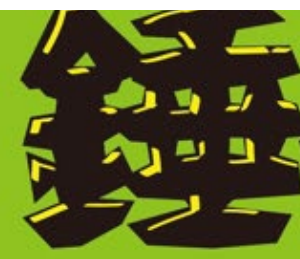

耿军 Geng Jun

制片人 Producers:

王学博郭冬 许飞雪

Sean Wang Guo 演员 Actors:

徐刚 張志鼻 薛宝鹤

Xu Gang Zhang :

WORK OF ARTS

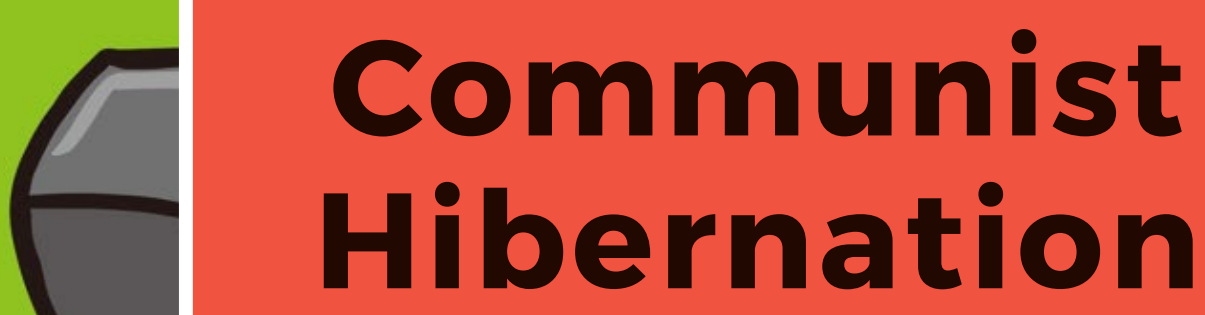

Christian SORACE

I recognise in thieves, traitors,

and murderers, in the ruthless

and the cunning, a deep

beauty-a sunken beauty.

Jean Genet

s Cultural Co. Ltd.

公司

Ilture Communication Co. Ltd.
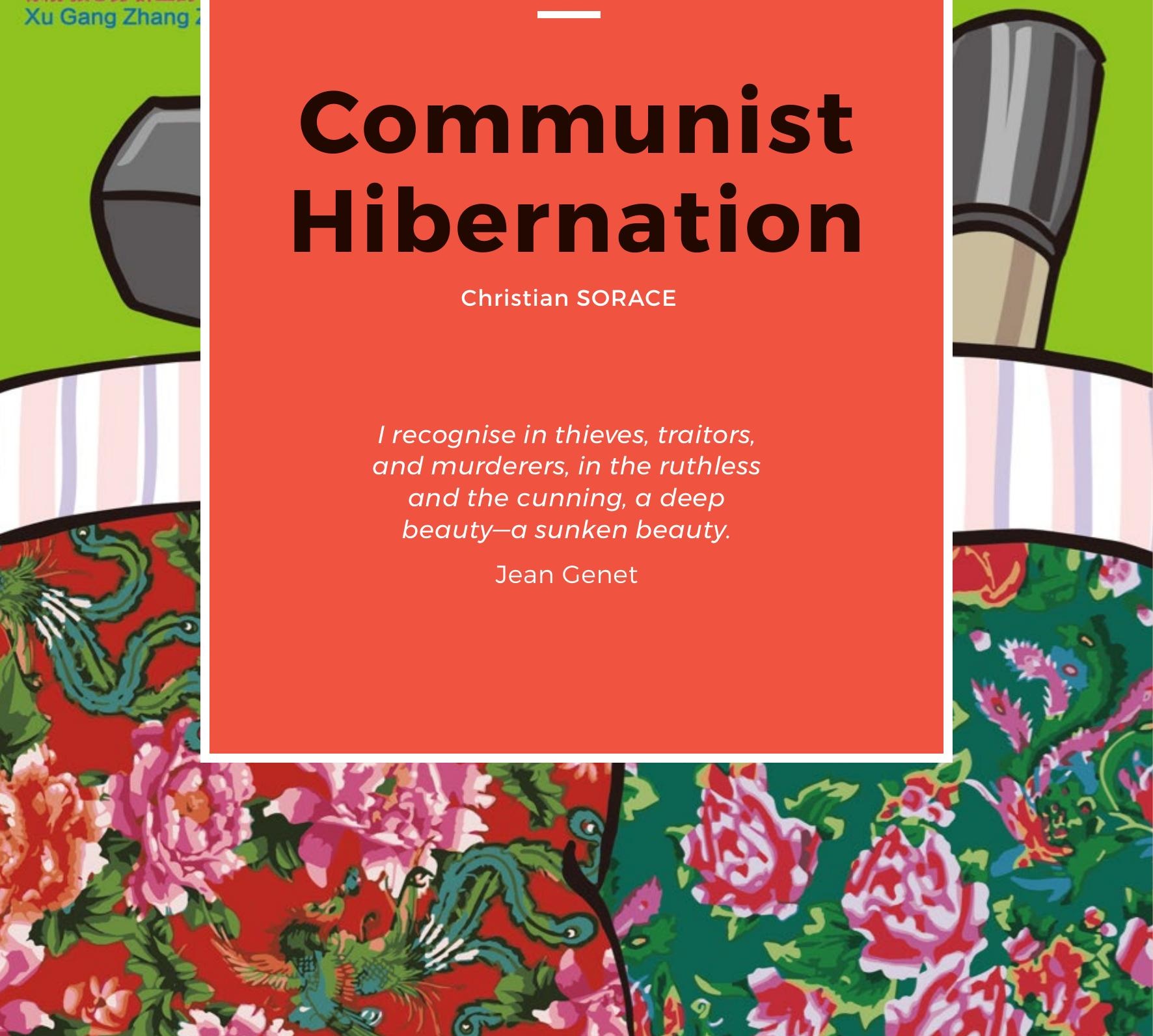


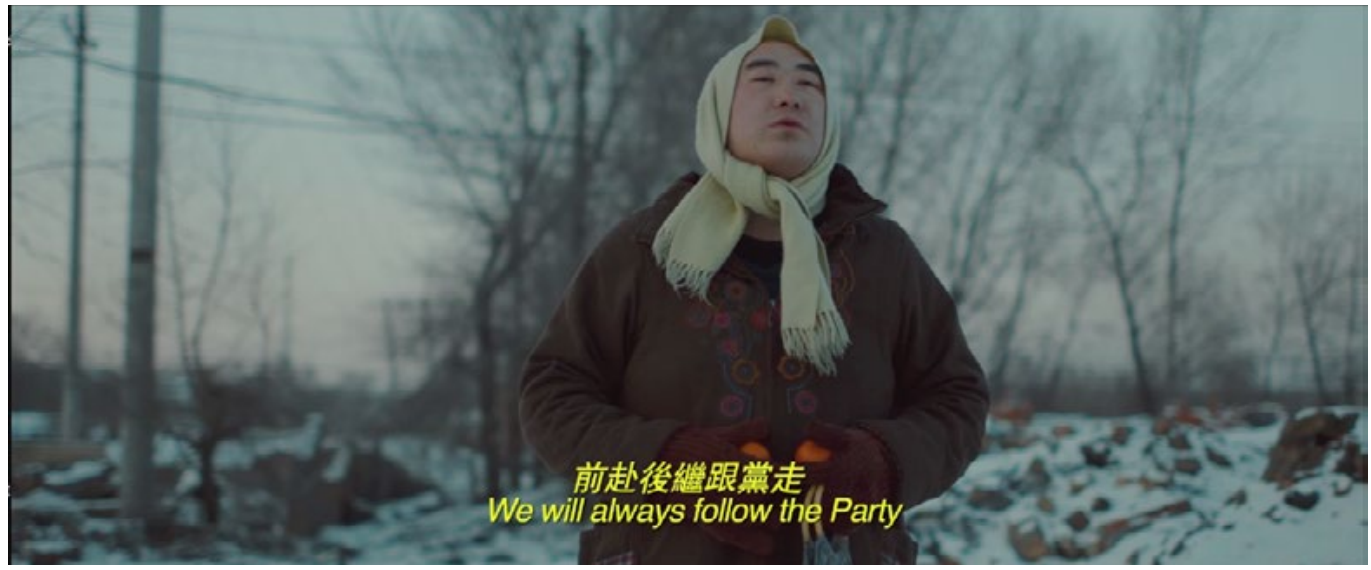

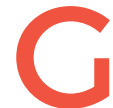

eng Jun's films are set in northeastern China where he grew up. As Geng Jun put it in an interview I conducted with him at a friend's studio in Songzhuang in August 2018:

When people watch my films, maybe they will see different actors and actresses and characters, but the main character in my films is the setting (changjing). I write my stories for the setting, which is the foundation of my expression.

The landscape of China's Northeast-also known as its rustbelt region-is inseparable from its political economy. During the Mao era, the Northeast was the heartland of heavy industry (in particular, steel and machinery), natural resource extraction (oil and coal), and collective agriculture (corn, sorghum, and wheat). Its workers and farmers stood proudly at China's symbolic vanguard. However, these same political economic factors that made it attractive under the socialist planned economy rendered it vulnerable to privatisation and liberalisation during the reform era. For state-owned enterprises (SOEs) located in the Northeast, layoffs began as early as the 1980s, but dramatically intensified after the Fifteenth Party Congress in 1997 during which 'it was decided that SOEs were to evolve into profitable firms and that a chief means to achieve this goal would be the laying off of
Still from The Hammer and Sickle Are Sleeping (2013). workers to cut costs' (Hurst 2009, 49). It is estimated that between 1997 and 2004 over 35 million workers were laid off throughout China (Hurst 2009, 35). This wave of layoffs had catastrophic effects on labour relations and the lives of workers in the Northeast. As Ching Kwan Lee wrote at the time: 'Many aggrieved workers find themselves going back and forth between passivity, depression, and even selfdestruction, on the one hand, and outbursts of rage, desperation, and heroic acts of collective defiance, on the other' (2007, 69-70).

In the early years of reform, natural resource extraction was profitable but at the steep cost of environmental destruction, which undermined its economic sustainability. Geng Jun recalls the early 1980s as a 'golden age of state planning' in which everyone wanted to go into mining because of the relatively high salaries and perks, such as 'salted duck eggs, cured meat, and bread'. But by the 1990s, 'some mines and oil fields became increasingly desperate as they began to exhaust their deposits of mineral resources, even as prices and markets for the commodities they produced were booming' (Hurst 2009, 44-45). In our conversation, Geng Jun describes the privatisation of 
natural resources as a process of theft and redistribution of wealth into the hands of people with political connections. In his words: 'After people destroyed the resources of the Northeast, and made their money, they left the area and took the money with them, most likely buying real estate in places like Beijing and Hainan.' Then he quickly adds that this is a familiar story and pattern throughout China.

In terms of agricultural production, the Northeast was once regarded as the bread basket' of the People's Republic because of bountiful harvests of staple crops produced at economies of scale (it was for this reason that it was also coveted by the defeated Japanese imperialists). The region also boasted among the earliest and most successful models of collectivisation in the late 1950s. Even in the 1980s, the Northeast was one of the only regions in China in which there was resistance to decollectivisation. As the 'urban form' began to envelope agricultural land (Sorace and Hurst 2016), the region's farmers also slowly lost their lands and livelihoods. The empty field is also a metaphorical condition of lifein Geng Jun's film Free and Easy (Qingsong yukuai, 2017), the characters frequently refer to their lives as huangfei, meaning fields that are no longer cultivated.

Geng Jun's movies take place in Heilongjiang province after two decades of continuous layoffs, disinvestment, and disrepair. With long panoramic and tracking shots of dilapidated buildings and abandoned fields, Geng Jun's camera reveals a landscape in which time has stopped-frozen between the no longer and the not yet. In his discussion of Béla Tarr's filmsanother director from a socialist backgroundJacques Rancière describes a similar phenomenon of 'the loss of revolutionary temporality and its future-orientation in which the present is a duration of abeyance and anticipation of the life-to-come' (2013). Recent attempts to revitalise the Northeast do not include-and perhaps do not even recognisethese people who Geng Jun describes as 'being abandoned by the age' (bei shidai shuai diao) and left with 'nothing to do' (wushi kezuo).
But Geng Jun does not offer sociological portraits of China's downtrodden. Instead, he films dark comedies that resemble what a Samuel Beckett play would be if it were staged in China's Northeast. Almost all of Geng Jun's characters are con artists and criminals with the twist that they are hilariously inept at crime. The cast of characters from his two recent films The Hammer and Sickle Are Sleeping (Chuizi liandao dou xiuxi, 2013) and Free and Easy include: a travelling soap salesman whose soap incapacitates anyone who smells it; a holy fool with a speech impediment and stuffy nose; a fake monk beggar; a pair of delinquent cops; a cripple; a man dressed as an elderly woman who sings revolutionary songs for money; a hapless forestry official; and laid-off workers who occasionally wander into the scene as targets of the various ongoing hustles. They are anything but the stereotype of cold-blooded criminals; in fact, there is something lovable about their mannerisms, and the sheer futility of their schemes. Besides, as Geng Jun put it, they have nothing else to do.

\section{Falling Asleep}

The title of Geng Jun's recent short film The Hammer and Sickle Are Sleeping conjures an image of a future that has gone away and is not coming back-at least not in any recognisable way. The once exalted emblems of proletarian unity-the hammer and sickle-are no longer put to work in constructing the future, but have become mute objects strewn amid empty factories and barren fields. Geng Jun explains his thinking behind the title in these terms: 'After farmers lose their land and workers lose their jobs, their tools become idle (gongju jiu xianzhi le). The hammer and sickle are sleeping. But at the same time, they can become weapons of self-protection (fangshen wuqi) or murder weapons (xiongqi).' Tools are no longer used for harvesting grain and forging metal, but are brandished as instruments of survival. A new twist to the Marxist stages of historical 


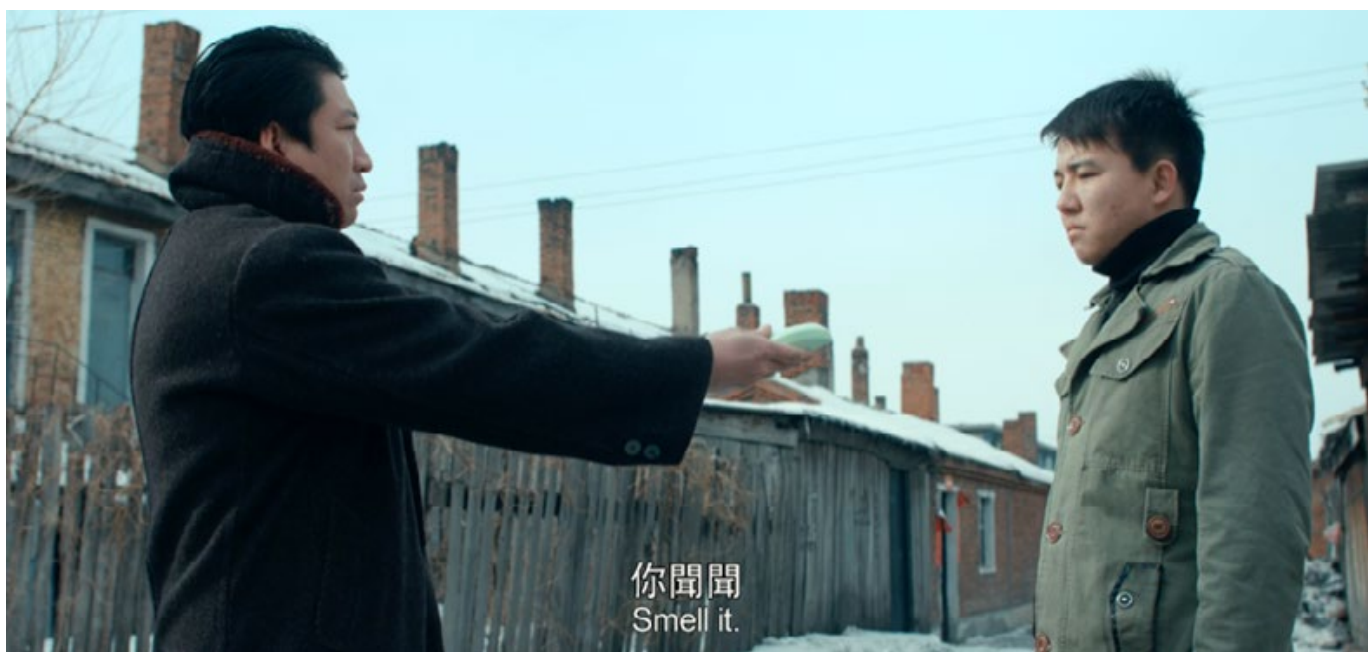

A travelling salesman asks strangers to smell the soap that he is selling-one deep breath and they fall unconscious. Still from Free and Easy (2017).

development: after farmer and worker comes the con artist and criminal. The title of the film, however, also refers to a sabbatical from violence. As Lunar New Year approaches, one of the main characters decides to take a holiday from crime, and writes in his diary on the wall of his apartment, 'the hammer and sickle are sleeping'. It is perhaps in the decision not to act that promises a utopia of pure potentiality.

But we are also disarmed and vulnerable when we are asleep. In Free and Easy, a travelling salesman asks strangers to smell the soap that he is selling-one deep breath and they fall unconscious.

The soap does not merely incapacitate but also induces pleasurable reveries. When the police show up to question three victims, one of the workers (played by Geng Jun himself) describes feeling '... like I was having a dream. It was hot, and I was thirsty. All the women on the street were wearing beautiful dresses. I was somewhere warm.' Impatient to solve the case, the police officer cuts short the worker's narration of his dream. Later in the film, the same officer tries a bar of confiscated soap on himself and passes out. When his partner asks: 'What was it like?', the half-conscious, beatific police officer responds: 'Free and easy.'

The magical soap is more than a mere plot device; it is also an ambiguous commentary on social life. From a tradition of critical theory, it is possible to interpret the soap as people's willingness to be duped and distracted from their own exploitation-the trope of going through life asleep. After all, the people are being robbed. But it also possible to understand the soap as providing a momentary respite from a world with nothing to offer.

\section{Fragile Solidarity}

In a land of cutthroat capitalist competition and survival, Geng Jun's characters are surprisingly tender and empathetic to the needs of others, even the people that they are robbing. 


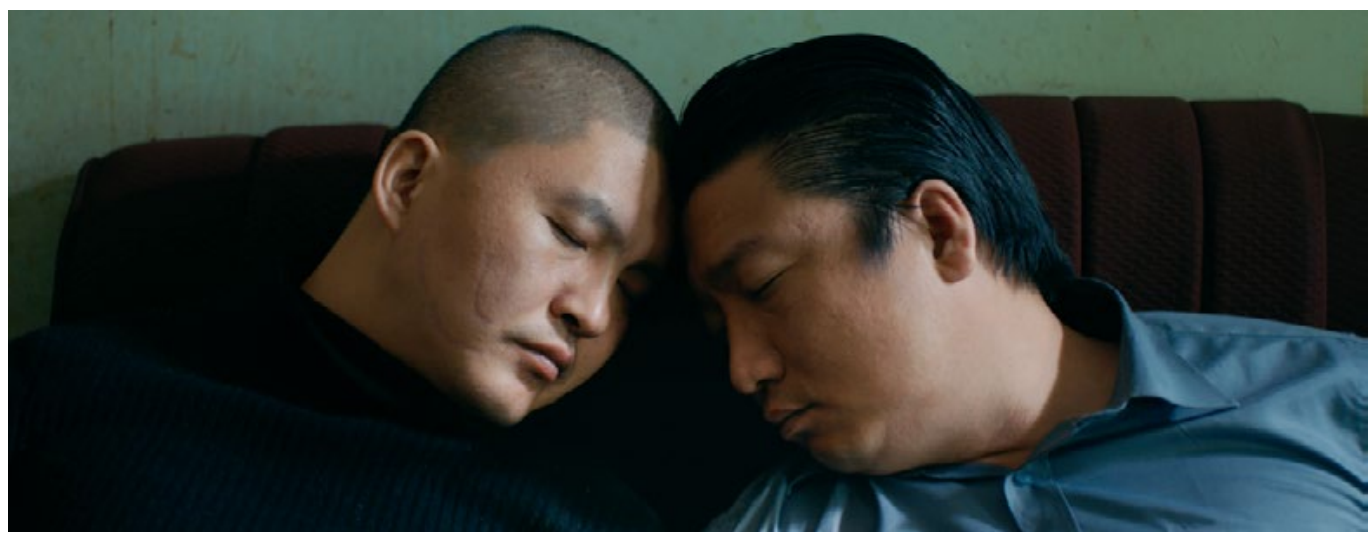

A moment of tenderness between thieves. Still from Free and Easy (2017).

When the thief in The Hammer and Sickle Are Sleeping holds up a man on his way home carrying fireworks, oranges, and a toy gun as a Lunar New Year gift for his son, he asks the worker about his present economic state. The man responds that his boss at the mine has not paid him for months. The robber hands back the toy gun to the man to give to his son, but keeps the oranges and fireworks. Later in the film, the robber breaks into a house and as he is leaving discovers a crippled man feigning to be asleep under the blankets (who also happens to be another swindler). As he is about to depart with the stolen money, the crippled man's nephew, who is a devout Christian, comes home and invites the robber to stay for dinner. When the nephew sings a hymn to God during dinner, the robber attempts to return the money to the person he stole it from, who refuses the offer. In this gesture of double-refusal, a friendship and future partnership is born. The same robber later encounters (unbeknown to him) the partner in crime of the crippled man who is standing on the side of the road dressed as an elderly woman. She tells him a predictable sob story: 'I am from out of town, I came to find my relatives, but they're gone. I've been here for days now, and I don't have any money left. Can you just give me a little cash to get home?' All he can offer her are two of the oranges he stole from the worker earlier in the film. As he walks home, she performs for him by singing 'Little Bamboo Raft' (xiaoxiao zhupai jiang zhongyou)-a song written in 1974 during the Cultural Revolution:

\section{The red star shining \\ Guiding me into battle \\ The Revolution rising like a wave \\ We will always follow the Party \\ Breaking down the old world \\ The new world stretches before us.}

The red star is dim and no longer illuminates a path forward. The optimism for the future in the song lyrics is conspicuously out of place in the desolate landscapes of Geng Jun's movies. It also produces a rather comical effect. According to Geng Jun, this scene in particular has attracted the disapproval of the authorities:

They thought that it wasn't appropriate for someone to beg for money by singing a revolutionary song. When I screen the movie, sometimes representatives from the local Chinese People's Political Consultative Conference (CPPCC) or Party members come and express their dissatisfaction. 
On the surface, there is a comic juxtaposition of a beggar singing a revolutionary songbut at a deeper level, it raises the question: who are the heirs of the revolution? As the Communist Party stays in power through the twin mechanisms of stability maintenance and capitalist exploitation, perhaps the genuine spirit of communism is incarnated in the homosocial tenderness among thieves and liars who have 'nothing to do' and no one to rely on but each other.

\section{Complicit Criminals}

For Geng Jun, referring to his characters as 'criminals' is misleading because everyone is a criminal in Chinese society:

All of us are criminals and participants [in the system]. It is because we are too weak and did not stand in the way that our situation has become like this. My stories are only a surface layer, but in my heart, an even deeper layer is that I am also, in fact, a criminal.

In this quote, the definition of criminal is expanded from its traditional usage in the court/penal system to indict all of society. Like his characters, Chinese people are victims of their own criminal complicity in the system which oppresses them. The ability to get by depends on a willingness to give in. Each decision not to act is a counterfactual history of the absence of freedom:

\footnotetext{
Why is everything messed up? Why is there collusion among officials and business people? Why do we suffer hardship? It is because we never resisted or fought. Instead, we believe that we are weak. I have never thought that I film society's lowest rung and weak groups. On the contrary, I think that I film the great majority of people ... . I don't know what
}

people mean by the term 'disadvantaged social groups' (ruoshi qunti) [author's note: ruoshi qunti is a sociological term in China referring to the economically and politically dispossessed].

It is a radical statement to say that there are no disadvantaged groups in China because everyone is complicit in the maintenance of the system. You are always someone's criminal and another person's victim. But Geng Jun's comment also draws on a familiar legacy that locates sovereign power in the hands of the people. This idea is conveyed in Mencius' famous statement: 'The time is not as important as the terrain and the terrain is not as important as having unity with the people ... an unjust cause finds little support' and well-known Chinese phrases, such as 'water can carry the boat or overturn it' (shui neng zai zhou, yi neng fu zhou). In Mao's account, as soon as the state separates from the masses, it becomes a 'paper tiger' (zhilaohu) that has become disconnected from the source of its power. Power is always ultimately in the hands of the people, even if they are unable to recognise it, let alone act on it.

Geng Jun finishes the interview on a pessimistic note: 'Individuals can accomplish very little on their own; communities can accomplish a lot more. But when individuals are powerless and communities are also powerless, all that remains is desperation.' But this may not be as bleak a prognosis as it seems. It is important to remember that desperation in Geng Jun's films does not take itself seriously. His characters seem to have adapted to their absurd circumstances, and are seldom discouraged by their constant failures. The insouciance of the criminal is also an emancipation from the solemn rituals of the state. Perhaps they have stumbled upon a powerful antidote to a Party-state that is incapable of laughter, and regards itself with a deadly seriousness. 
This text is taken from Dog Days: A Year of Chinese Labour, Civil Society, and Rights, Made in China Yearbook 2018, edited by Ivan Franceschini and Nicholas Loubere, published 2019 by ANU Press, The Australian National University, Canberra, Australia.

doi.org/10.22459/MIC.04.2019.44 